\title{
Death of a Salesman and The Glass Menagerie: A Phenomenological Reduction
}

\author{
Bakhtiar Naghdipour \\ Faculty of Education, The American University \\ P.O. Box 5 Karmi Campus, Karaoglanoglu, Girne, Cyprus \\ E-mail: bakhtiarnaghdipour@gau.edu.tr
}

Received: 19-01-2013

doi:10.7575/aiac.ijalel.v.2n.3p.147
Accepted: 25-03-2013

Published: 01-05-2013

\begin{abstract}
Tennessee Williams and Arthur Miller were two memory playwrights who searched the memory or the collective unconscious of their generation for the lost dreams of an unspoiled myth as well as the genuine ideals of love, humanity and dignity. These authors employed techniques and mechanisms such as poetic language and expressionistic stage directions to translate the inner workings of their characters into artistic projection. This paper employs the phenomenological principles of Geneva School of criticism with the aim of reducing the immediate consciousness of Williams and Miller, projected as stories of Tom and Willy, in search for the playwrights' attitudes towards some basic concepts of life in the modern era.
\end{abstract}

Keywords: Death of a Salesman, The Glass Menagerie, memory play, phenomenological reduction

\section{Introduction}

Phenomenology "is a transcendental philosophy interested only in what is 'left behind' after the phenomenological reduction is performed, but it also considers the world to be already there before reduction begins" (Audi, 1999, p. 665). Edmund Husserl contended that objects could be regarded not as things in themselves but as posited or 'intended' by consciousness where we can grasp their essential features through the mental process of reflection (Selden, 1989). This differentiates phenomenology from phenomenolism whereby "we have access only to phenomena, not to the real things" (Hintikka, 1995, p. 78). Ingarden, who applied Husserl's theory of phenomenology to literature, distinguishes between autonomous and heteronomous objects in order to define the domain of literature:

While autonomous objects have immanent (i.e. indwelling, inherent) properties only, heteronomous ones are characterized by a combination of immanent properties and properties attributed to them by consciousness. Thus heteronomous objects do not have a full existence without the participation of consciousness, without the activation of a subject-object relationship. Since literature belongs to this category, it requires 'concretization' or 'realization' by a reader. (cited in Rimmon-Kenan, 2002, p. 119)

In the late 1930s, reader-response theories and approaches to reading literature mushroomed with an emphasis on the readers and their active role in reading. However, literary texts contain gaps, unwritten words and sentences, and figurative elements that could make the interpretation of these texts challenging and difficult. "No tale", says Wolfgang Iser, "can be told in its entirety" due to these gaps and omissions we as readers have to fill in when we are given the opportunity "to bring into play our own faculty for establishing connections" (cited in Selden, 1989, 128). The phrase "where am I" that resonates across the work of Georges Poulet is also a philosophical question which demonstrates the importance as well as difference of reader or 'textual consciousness' from the 'biographical author' (Selden, 1989, 104). Phenomenology also poses the historical question of subject and object by glorifying the subject or reader at the center of the great chain of being. It is a philosophy that, as Eagleton (1989) believes, has

Restored the transcendental subject to its rightful throne. The subject was to be seen as the source and origin of all meanings: it was not really itself part of the world, since it brought that world to be in the first place. In this sense, phenomenology recovered and refurbished the old dream of classical bourgeois ideology. (58)

The significance of phenomenological reduction is the amount of freedom it grants the reader to see a play as a phenomenon appeared to the main actor's consciousness, which emerges to the outside world as a work of art. Although the works of Williams and Miller have some connection with their personal and family life, there is a universal living consciousness at the center of their works. The Glass Menagerie and Death of a Salesman could be viewed as mere phenomena carved on Tom's and Willy's minds - memories of the characters' uneasy conscience trying to lay the past to rest and to clear out the scarlet of the guilt, as it had interfered with the normal flow of these characters' lives. Bigsby (1997a) states that, "memory has become myth, a story to be endlessly repeated as a protection against present decline" (p. 38). He further maintains that "Tom Wingfield recalls the past for much the same reason that Willy Loman does in Death of a Salesman: guilt" (p. 37).

While reflecting on the past, Tom and Willy re-live it by projecting their mental load on different characters. Both authors broadened the memory scene to allow their audience or readers access the life of their characters. Miller wanted 
a play to "formulate a dramatic structure that would allow the play textually and theatrically to capture the simultaneity of the human mind as that mind registers outer experience through its own inner subjectivity" (Roudane, 1997a, p. 72). In Death of a Salesman, the events and what other characters do seem to be projections of Willy's consciousness. For example, one such character is Willy's wife, Linda. Whenever Willy seems to doubt himself in the "past" scenes, Linda is there to reassure him that he is really a good salesman, that he is "the handsomest man in the world" (24). After Willy is fired in Act II, he recalls the time Ben, his brother, offered him an opportunity in Alaska. Willy wanted to go to Alaska with Ben, but Linda stopped him, giving him the illusion that he was doing well enough. Linda always reinforced Willy's illusion that he was successful. And then there is Willy's affair with the 'Woman' in Boston: the guilt - the figure of 'The Woman' he feels about betraying Linda is also an essential part of his consciousness, and indeed has occupied most of it. Biff and Happy are not only two parts of his personality - Biff, the "poetic" and "ideal" side and Happy, the foolish and childish side - but also they are the "Inheritors of Willy's sins from the past, [...] are flawed extensions of Willy and Linda, the genetic lineage carried on with devastating efficacy and symmetry" (Roudane, 1997a, p. 69).

In The Glass Menagerie, the events are also unfolded as they are projected on Tom's mind. Thus, Tom's personality has five parts: Amanda, the representative of heroism, endurance and foolishness; Laura, the lack of self-esteem and crippleness; Jim, the feature of being young and ordinary; Tom, the aspect of creativeness; and Mr. Wingfield, the desire to escape. As Tom's soliloquy tells the audience at the beginning of the play, the most realistic character will cover the least part of his personality. Therefore, it is the portrait of the Mr. Wingfield, the desire for freedom and independent, which occupies the most part of Tom's personality, as the least part is covered by Jim's part (Haley, 1999). Hammer (2002) also maintains that "Laura is the hidden aspect of Williams himself: the hysterical, withdrawn, secretly desirous, feminine crippled artist" (p. 45).

\section{Discussion}

\section{1 'A dime a dozen' characters}

Willy and Tom are both anti-heroic characters who are even against themselves - being antagonist and protagonist at the same time. From the beginning, they are aware of what has gone wrong and are struggling to amend it, but that feeling is so strong that ultimately destroys them. Awareness of the past is always an element in Williams' plays, as well as in Miller's. Their characters live beyond the fleeting moments of the drama - back into a glowing past and shrinking from a terrifying future. Laura is the character on whom Amanda is placing all of her hopes: if Laura achieves a business career, or finds a husband, then Amanda's problems will be partially solved. In this aspect Laura is similar to Biff in Death of a Salesman. Although Willy has two sons, it is clear that Biff is the focus of Willy's entire life. He takes Happy for granted, just as Amanda seems to take Tom for granted. While Tom and Happy both have steady jobs, both Laura and Biff are unemployed. While Happy may not be able to "retire [Willy] for life" (28), he is earning money and is able to lend some to his parents. Similarly, Amanda relies on Tom to earn the living for the family and to bring a gentleman caller for Laura. Amanda and Willy, then, are very dependent on Tom and Happy, so it is ironic that they fail to appreciate them. It is also ironic that Laura and Biff are both lost characters in that they failed to accomplish much after high school. Both characters live in their dreams: Laura occupies herself with her glass menagerie inside house, while Biff, living mostly outside, goes from one job to another, unable to get along. Like Laura, he stopped maturing as a person after graduating from high school and the last thing Biff achieved was a high school football glory. But in this respect Biff also resembles the gentleman caller, Jim. Tom says that Jim was a hero during high school, "but apparently ran into more interference after his graduation from Soldan. His speed had definitely slowed. Six years after he left high school he was holding a job that wasn't much better than mine" (31).

Williams calls Jim "an emissary from the world of reality" (2), as he seems to face life more realistically than the other characters do. For example, he has a steady job, which earns more than Tom's job; he has good social skills; he is aware of new developments in technology (radio, television) and is going to night school to develop his public speaking skills in order to prepare for a new career. As Amanda suggests, Jim seems to have "visions of being advanced in the world!" (29). Ben is like Jim in that he had visions of being advanced in the world, but Ben acted on those visions: he achieved what he wanted to achieve. So Jim was ambitious, but unlike Ben, he hasn't actually achieved these dreams yet. In his introduction to scene six, Tom says that Jim didn't achieve much after high school, suggesting that Jim is a rather ordinary person, though as a student he seemed very successful. Perhaps Jim was just overly confident as an immature young boy. For example, when Jim meets the rest of the family, he seems not a great hero but simply an ordinary person. Jim accidentally breaks Laura's glass unicorn, and soon after, he confesses that he is already engaged. Thus, Jim seems very ordinary even to Laura, who gives him the broken glass unicorn to take home with him - because now the unicorn, like Jim, is also "ordinary", and "just like all the other horses" (54). This further shows that while Tom resembles Happy, Jim has something in common with both Biff and Laura: like them, he failed to be successful as an adult. However, in Act I Happy calls Biff "a poet" and "an idealist" (13) - and Tom has certainly these attributes, too. Laura and Tom, like Biff, are also sensitive - Tom (Williams) because he is an artist and Laura because she is shy and imaginative. The reason for his being sensitive and neurotic is that since Tennessee Williams' father was a traveling salesman and frequently away from home, as a boy Williams spent a lot of time in solitude or at his maternal grandfather's home, and library.

As far as female characters are concerned, both Amanda and Linda are the victims of love for unworthy men, who betrayed them. However, they play some roles to keep the status qua safe and sound. They also possess the power of enabler and are always afraid of being abandoned and ruined by the cruel insecurity of the society. They try to pay much attention to the situation of other members of the family, especially the family's breadwinner. For example, 
Amanda wants security that is oppressive to Tom as she nags him, "What right have you got to jeopardize your job? Jeopardize the security of us all?" (14). She neglects the need in Tom for independence and freedom and tries to do her surveillance job and put him under pressure even to the determent of his heath and life: "I saw that letter you got from the Merchant Marine [the symbol of homelessness]. I know what you're dreaming of. I'm not standing here blindfolded" (22). Encountering a difficult situation, she resorts to those pure and metaphysical Southern relics and rituals. For example, she asks her children to look at "the moon" and make "wish on it" (25). Sometimes she blinds her eyes to the facts when something is about to go against her wish. That is why she fears the future as well as the time, as time is what her husband fell in love with, and also what has left her in her loneliness. In other words, she prefers to stick to the past which is "Gone, gone, gone. All vestige of gracious living! Gone completely! I wasn't prepared for what the future brought me" (40).

Linda also does encourage Willy sycophantically from the beginning of the play: "You're too accommodating, dear" (6). Then she tries to take control of the situation, and also of Willy - the family's security provider and breadwinner. She advises him to share his problems with others to make money, by asking him, "Why don't you tell those things to Howard, dear?" (7). Willy, who is already encouraged, blindly agrees that, "I will, I definitely will" (7). Like Amanda she also does family's auditing and accounting job, and at the right moment "she pulls pencil and paper out of her apron pocket" (22), and determines Willy's commission. It seems that her security is more important than her husband's health, because there is enough evidence from the beginning Willy is going to kill himself. It is also likely that she is aware of Willy's betrayal of her love and intends to take her revenge; in so doing, she pushes him ahead and accelerates his plight: "But you're doing wonderful, dear. You're making seventy to a hundred dollars a week" (24). Here her tyranny is like what Amanda confesses at the end of The Glass Menagerie: "Yes, I know----The tyranny of women!" (60). She knows that "he's not easy to get along with - nobody knows that better than me - but..." (39), and ironically tells her children that "Attention, Attention must be finally paid to such a person" (39), because "he's dying" (41).

\subsection{Memories on the stage}

Both authors endeavored to violate the conventional means of playwriting and stage presentation in an attempt to recover a 'past' and create a 'future' in the 'present' time. They introduced the genre of memory play to tell memories of the lost love, life, and the unfulfilled dreams of the youth as well as the old in the American society. Miller said in an interview in 1995 that, "The plays are my autobiography. I can't write plays that don't sum up where I am. I'm in all of them. I don't know how else to go about writing" (Bigsby, 1997b, p. 1). In a similar way Williams also asserted that:

If the writing is honest it cannot be separated from the man who wrote it. It isn't so much his mirror as it is the distillation, the essence, of which is strongest and purest in his nature, whether that be gentleness or anger, serenity or torment, light or dark. This makes it deeper than the surface likeness of a mirror and that much more truthful. (Haley, 1999, p. 6)

Among the use of radical means of presentation, transparent walls in both plays allow the characters to move fluidly from the dismal present to the more hopeful past. The Wingfields' apartment is located in "an overcrowded urban center" (1); the Lomans' Brooklyn home is similarly boxed in - though the neighborhood was supposedly greener in the past. Yet the homes are described at scene one as "one interfused mass of automatism" (1). This suggests an "every man for himself' or 'survival of the fittest' world, like the one in which the Lomans are trapped; and like the Lomans, the Wingfields are having trouble surviving in this world. The fire imagery also introduced in the opening stage directions has so many implications for the two families, suggesting that they have entered a critical phase in their lives. In scene six, Tom complains that it's "so warm already" that they are "going to burn up when summer really gets started" (40). There is also much fire imagery in Death of a Salesman, and it symbolizes the same thing; that is, the increasing desperation of Willy's situation, the idea that his life is under pressure: "The woods are burning!" (28). At the same time, the fire escape suggests the possibility that the characters could escape their oppressive environment, as Tom does leave home at the end of the play by fire escape. In Death of a Salesman, Miller writes that "the blue light of the sky" (4) falls upon the house and forestage. This blue sky symbolizes the possibility of freedom, in much the same way as the fire escape does for the Wingfields. In addition, a fire - the fire of creativity, of imagination - is burning inside Tom, as he has a desperate need to create, or write. He realizes that if he does not leave home, the fire will destroy him, and he will never be the writer he dreams of being: "I'm starting to boil inside. I know I seem dreamy, but inside - well, I'm boiling!' (39).

Tom cannot live in a house where his creativity is not appreciated; if his own mother does not appreciate the talents of D. H. Lawrence, then she will never understand Tom's literary abilities. Amanda tells him angrily that she "took that horrible novel back to the library - yes! That hideous book by that insane Mr. Lawrence" (13). Thus, Tom leaves home because he must, but his sensitive personality does not let him forget his sister, and her delicate and remarkable beauty. This is the reason for recounting her sister's story because Tom is also a poet and writer, and his poetic language echoes throughout the paly. Examples are his opening line, "I have things up my sleeve" (2), and "They call me - El Diablo" (15), or his closing line, "Blow out your candles, Laura - and so good-bye...." (63). Candles, incidentally, are frequent poetic images in Williams' plays as Blanche in The Streetcar Named Desire uses and talks about them, and of course in The Glass Menagerie Jim and Laura have a chat in the candlelight.

In opening stage directions provided at the play's preface In Death of a Salesman, "An air of the dream clings to the place, a dream rising out of reality" (1) - the Lomans's house; the surrounding area and stage directions in The Glass Menagerie, as Williams himself explains, also represent a scene of a memory. That's why the action is not presented in a strictly logical order, but as a series of episodes, only the most important of which are included. For instance, we do not see the family's preparation for the gentleman caller's arrival; we see only his actual visit. This is an imitation of the 
way that memory selects some events as more memorable than others; it tends to recall the most important events and to forget non-essential stuff. In Death of a Salesman, Willy's past is seen through by his present mind: in a similar way, Tom's memory is selective: it chooses the most important events and discards the rest. Tom is the narrator of The Glass Menagerie, but Willy seems not to be the narrator of the play although the events are shown as he sees them. There is much likelihood that Tom is exaggerating the past, since it is being presented strictly through his eyes. For instance, he is making his mother more shrewish than she really is and himself more innocent. Willy does a similar 'editing job' on his past life, but since there is doubt that he is the narrator of the play, the past scenes have more the character of reality - as though they are being presented by Miller himself. Tom, as narrator, might be distorting the truth to some extent, but the audience would never know this because Williams presents the play as Tom's story. Miller's characters speak selectively and hence poetically, too, because memory seems to recall the past in a metaphoric manner; there are many phrases in his plays that have both the rhythm and the vivid imagery of poetry. "Liked but not well liked" (19); "The woods are burning, boys," "When I was seventeen I walked into the jungle, and when I was twenty-one I walked out. And by God, I was rich!" (33), and of course, Willy's poetic words, "Spite, spite is the word of your undoing!" (96). However, Williams' language seems to be more "poetic" than Miller's because his language relies less on cliché; Miller's language tends to be that of the common man; for example, Willy's "Liked but not well liked" and his reference to the "Hastings refrigerator" (51). Also, Miller repeats his famous phrases again and again in the same play, whereas Williams tends to use them once only. However, Williams does repeat the blue roses and candlelight images and that poetry itself uses a lot of repetition. Therefore, it appears that Miller's language is actually as poetic as Williams', but in a different way: it is the poetry of the consumer, of the 'common man'.

\subsection{Tragic memories}

Williams' plays in general have less of a social conscience and are more confined to the family. Miller's plays concern the family but ultimately go beyond this: for example, Willy's predicament makes us partly blame a society that "eat[s] the orange and throw[s] the peel away" (58), and in All My Sons Joe Keller's crime affects both his family and others and eventually he must learn that 'others' are his family. Death of a Salesman contains several elements of a classical tragedy. For instance, the mood becomes optimistic halfway through the play; this also happens in the Greek tragedies and in Shakespeare plays like Romeo and Juliet. When Biff is about to meet with Bill Oliver and Willy is about to ask Howard for another job, the drama becomes hopeful; it looks as though the Lomans could succeed. That they do not succeed is what makes this play tragic. A similar situation occurs in The Glass Menagerie, when Tom announces that he has invited Jim to dinner. Amanda begins cleaning the house and getting ready for his arrival; it looks as though Jim will be the man who will marry Laura and solve all of the family's problems. But Jim turns out to be an ordinary person and moreover is already engaged to marry someone else. Yet the main characteristic of Greek tragedy is that the protagonist has a tragic flaw that causes him to act wrongly and then be punished because of his wrong actions. There is also a curse on the Loman's family; if Willy had not betrayed his family in this way, Biff would not have lost heart and given up trying to 'succeed'. With Willy's values could Biff ever have succeeded in the world of business? In Act II, Willy reminds Howard that he named him, but this fact means little to Howard. And later, Charley asks Willy: "When the hell are you going to grow up? ... The only thing you got in this world is what you can sell. And the funny thing is that you're a salesman, and you don't know that" (64).

These incidents suggest that with Willy's values, Biff becomes a lost individual because he has no values of his own all he knows is what Willy taught him. Thus perhaps the curse is caused mostly by Willy's sin and partly by the fact that Willy and Biff were always unfit for the world of business. To offer an apology to a lost love or a wasted life, Willy's suicide is justified: Willy must apologize for violating his family's love by having an extramarital affair, a serious crime that caused a breaking of ties between father and son, hence between generations. Willy's life after the hotel room is tainted by guilt, and Biff has also been profoundly affected by his discovery of his father's betrayal. Ultimately, Willy commits suicide in order to pay for having lost Biff's love. In the final minutes of the play Willy says, "Isn't that - isn't that remarkable? Biff - he likes me!" and Linda confirms that, "He loves you, Willy!" and Happy adds, "Always did, Pop" (99). Willy loves Biff so much that he must die for him. In other words, Willy had to kill himself because he never 'gave' Biff anything during his life, so he tries to give him something - the insurance money after death. Miller (1950) himself said that, "To me the tragedy of Willy Loman is that he gave his life, or sold it, in order to justify the waste of it".

Excessive pride is another old concept that characterizes the tragic figure in these plays as well. Willy is too proud to accept Charley's job offer in Act II as he tells Charley "I can't work for you" (71), and Charley suggests this because Willy is jealous of him. Likewise, he is too proud to admit to Biff that he was wrong to have an affair with that woman and tells him "She's nothing to me, Biff. I was lonely, I was terribly lonely" (89). Then he demands that Biff "apologize for that" (89), which is a very prideful behavior on Willy's part. In addition, although Willy and Tom are common people, not of noble birth, Death of a Salesman seems more likely to imitate classical tragedy mainly in its acceptance of the principles of individual's responsibility and the ultimate sacrificing of sinner in order to re-establish the order. Williams also is concerned with Shakespearean themes of ruthlessness and power. For example, Amanda can be compared to Lady Macbeth: both characters want something: Lady Macbeth wants the throne, and Amanda a gentleman caller. Both will undergo some trouble to achieve what they want. And in both plays, one isn't quite sure whom the character is fighting for - another person, or herself. For instance, Lady Macbeth pushes Macbeth to seize the throne, but she really wants the throne partly for herself, so she can be queen. Similarly, one suspects that Amanda wants the gentleman caller to pay attention to her, not to Laura; when Jim arrives, Amanda enters wearing a dress she wore as a girl. There is also the theme of desire resulting in death. Othello and Desdemona desire each other, and for a short time 
they achieve happiness as husband and wife, but before very long, tragedy happens, and both characters die. Willy and Tom each desire something, but this desire causes harsh penitence for Tom and death for Willy. For instance, Tom desires freedom, but at the end of the play it is evident this desire has destroyed him (although it happens inside him). Tom apologizes for abandoning his mother and sister by leaving home to pursue a life of creativity and freedom. However, in leaving home he gains only a life without love (i.e., Laura's love), and this 'breaks' the sensitive Tom. Thus, in a sense Tom apologizes for his desire to be free.

These plays also begin with the falling action and crisis as the audience sees Willy at the first scene with two heavy suitcases, which could stand for the burden he is carrying on his shoulder. The title of Miller's play, Death of $a$ Salesman, emphasizes the tragic sense of the play and also the mere proof of the familial crisis or dysfunctional model of life from the beginning, where "Death stands everywhere in the background and to it every well or ill-spent moment brings us closer and closer" (Dukore, 1989, p. 39). The audience also sees Tom standing on the fire escape with the especial clothes of Merchant Marine at the very beginning of the play telling them of his experience. Furthermore, his argument with Amanda and then Laura's silence and innocence, symbol of love, allude to the growing crisis in the family.

In spite of Miller's overt moralizing, there is less of didactic element in Williams' play, which is a striking difference between Williams and Miller. But there is no doubt that Williams' play is also as tragic and sad as Miller's play is. It is a tragedy related to the familial problems and a conflict between an escaped father and his son forced into his father's role. Years later Williams commented that, "It is the saddest play I have ever written. It is full of pain. It's painful for me to see it" (Hammer, 2002, p. 45). On the other hand, Death of a Salesman is not a simple story "In the service of a particular ideology", and instead "It concerns the fundamental practical and metaphysical question: what does it mean to be fulfilled in one's very existence?" (Bigsby, 1997b, p. 78). Miller sees Willy's tragedy as that of everyman, as it generated approximately the same reaction after its performance in many countries across the globe. After Beijing production of Death of a Salesman, Miller commented that, "Willy was representative everywhere, in every kind of system, of ourselves in this time", a type, "which was to excel, to win out over anonymity and meaninglessness, to love and be loved, and above all, perhaps, to count" (Miller, 1987, p. 184).

\subsection{The conflict of ideals}

Both plays are replete with the scenes and dialogues that display the conflict between individuals' tendency to follow their own dreams and the exerted pressure from the society to conform to the social and family values, norms and obligations. Laura's complex is involved in what Jim tells her as "A lack of amount of faith in yourself as a person" in a world that is "full of common people" (51). Tom doubts Amanda's motto, "Don't quote instinct to me! [...] Christian adults don't want it" (21), and then follows in his father's footsteps. He goes as far as he likes, but something haunts him throughout the play, as he cries it out at the end: "I am more faithful than I intended to be!" (63). Tom's recognition of love, loyalty and responsibility distinguishes him from Jim's social ideals of "Knowledge - Zzzzzp! Money Zzzzzp! - Power!" (52). Tom, whose story the play is, is torn between his creativity and his obligation to provide for his family financial support by taking a job he hates. Tom is a sensitive person because he is an artist; however, when his creativity is stifled, for example, when he has to do his factory job, and when Amanda takes away his D.H. Lawrence book, he becomes angry, defiant, and even violent. Tom is not really a violent person, but he feels he must protect his creative instincts at all costs; hence the shouting scenes between him and Amanda. Thus the hard practicality of life the necessity of earning money - stands in the way of Tom's deeper, finer, and creative side. It is ironic, then, that in order to truly follow his creative instincts, Tom must ultimately act ruthlessly and leave his mother and sister. One finds Laura in a similar dilemma: because she is a woman, she must either pursue a career - the only option for an unmarried woman - or marry. But the shy and sensitive Laura would be much happier listening to music and caring for her glass figures, which represent her fragile world of illusions.

In The Death of a Salesman, Willy sticks to the social values of happiness and success, unaware or ignorant of who he is and what he is doing. In Act II, Willy tries to make his boss, Howard, give him a job in New York. He tells Howard that Mr. Wagner, Howard's father, once "put his hand on my shoulder" (58), and that he even "came to me the day you were born and asked me what I thought of the name Howard" (57). Because Mr. Wagner liked him, Willy sees the New York job as a favor Howard owes him. But this reasoning is erroneous and Howard sees that Willy cannot make sales anymore; therefore, he is useless to the company and must leave. The conflict between the opposing mentalities of Howard and Willy reaches a climax when Willy shouts, "I put twenty-five years into this firm, Howard, and now I can't pay my insurance! You can't eat the orange and throw the peel away - a man is not a piece of fruit!" (58). Willy feels that his resources have been used up by the world of selling and buying. It is the tragedy of the salesman that once he can no longer do business, he is discarded. His dire situation strips him off dignity and respect, because he has already lost these values in his own personal life. His wrongdoing has made him crippled, and his sons never help him as well. He tells Howard humbly, "I can't throw myself on my sons. I'm not a cripple!" (60). Later, Charley sums up Willy's dilemma when he tells him, "The only thing you got in this world is what you can sell. And the funny thing is that you're a salesman, and you don't know that" (70). If Willy placed more value on his real skills and less value on being 'liked', the social value, he would not be in the unfortunate position he finds himself at present - and neither would his sons. Instead, the Lomans might be successful, as Charley and Bernard are.

The Lomans are consumed by a driving ambition to prove themselves in the world of business. But they cannot do so because it is clear that Willy, Biff and Happy are not cut out for the life they want so much. Willy turned down Ben's Alaska proposal in order to stay in the city and build something with his company. Similarly, Happy postpones going "out west" (13) with Biff because he must first become merchandise manager. Therefore, in Death of a Salesman the 
drive to obtain the materialistic wealth seems always to get in the way of higher-level needs. While it may seem that he wants to be "well liked" (16) so that he can attain more wealth and power, in his conversation with Howard Willy indicates that what he really desires are the ideals of those (old) days; that is, "Respect, and comradeship, and gratitude" (58). He confesses that, "Today, it's all cut and dried, and there's no chance for bringing friendship to bear - or personality" (58). Thus, the conflict of ideals is shown as the projection of the uneasy mind of the modern man whose 'woods' like that of Willy's are 'burning' and like Tom is 'boiling inside'.

\section{Conclusion}

Death of a Salesman and The Glass Menagerie are modern plays with modern heroes concerned with domestic or bourgeois mentality and lifestyle. The so-called modern 'everyman' is striving hard to boost his bourgeois spirit, which has put him at the forefront of struggling for social acceptance. Because the bourgeois consciousness of guilt and sin has become so weak, this hero always dreams of worldly power and wealth, and indifferent to the mysterious aspects of life such as love, friendship, respect, and gratitude. The detailed stage directions, expressionistic techniques and realism used by these authors are contrivances to show their audience the inside of their characters' minds. In Death of a Salesman, Miller's realism ensures that the audience is not alienated by non-realistic - flashback or daydream sequences. This is the technique by which Miller shows us the troubled inner worlds of his characters. This also indicates that these playwrights lost their hope in people's taste in ambiguous art and imagination in favor of materialistic obsessions; that's why Williams does project some symbols on the wall to magnify their importance or significance. Miller also justifies the use of ordinary language by saying that, "Metaphor is dangerous, ambiguous; it leaves people slightly mystified" because "the conscience of the American theatre is that of an intelligent business man" (Bigsby, 1987b, p. 73). In addition, through the manipulation of some forms of presentation, both authors show their characters' susceptibility against the power of time: Ben shouts at Willy at the end of the play and reminds him of the time; Tom also ironically confesses that his story is timeless. In the world of art he also, as Roudane (1997b) states, does accordingly that has the characteristic of being timeless as he was fascinated with and devoted to art just to "outlive even the traumas of history". In other words, "He was wedded to theatre whose form and whose substance exposed the nature of the paradox, as it offers truth through lies and reveals a tensile strength in the most fragile of creations" (Roudane, 1997b, p. 58).

In both plays love is depicted as a highly invaluable possession; it is what for which Willy sacrifices himself and for which he, the father figure, kneels before Biff, the son. The tragic death is the result of Willy's love for his son, because the woman in the hotel room has no name and identity but a symbol of the sexual love, which could stand as the impediment to the real and pure love of a father for his son or vice versa. In the same way, Tom's perpetual guilt complex is his lost love for his sister and his mother, and for forgetting those pure Southern ideals Amanda reminds him of: "I don't know why my son is so stand-offish - that's not Southern behavior!" (40). For Amanda, "The South forms an image of youth, love, purity, all of the ideals that have crumbled along with the mansions and the family fortunes" (Tischler, 1965, p. 101). Through identifying with these characters, the reader comes to understand that both authors integrated history with fiction to blur the boundaries between the real and fictional time in order to make their experiences, memories, or phenomena timeless. What is left after this phenomenological reduction is a simple story of an innocent and transcendental love, whose betrayal has always been tragic.

\section{References}

Audi, R. (Ed.). (1999). The Cambridge Dictionary of Philosophy. (2nd ed). Cambridge: Cambridge University Press.

Bigsby, C. W. E. (1997a). Entering the glass menagerie. In Roudané, M. C. (Ed.), The Cambridge companion to Tennessee Williams (pp. 29-44). Cambridge, UK: Cambridge University Press.

Bigsby, C. (Ed.). (1997b). The Cambridge Companion to Arthur Miller. Cambridge: Cambridge University Press.

Dukore, B. F. (1989). Death of a Salesman and the Crucible: Text and Performance. Atlantic Highlands, NJ: Humanities Press International, Inc.

Eagleton, T. (1989). Literary Theory: An Introduction. London: T. J. Press.

Haley, D. E. (1999). Certain Moral Values: A Rhetoric of Outcasts in the plays of Tennessee Williams. Unpublished Dissertation. University of Alabama.

Hammer, S. B. (2002). That Quite Little Play. In Gross, R. F. (Ed.), Tennessee Williams: A Casebook. London: Routledge.

Hintikka, J. (1995). The phenomenological dimension. In Smith, B. \& Smith, D. W. (Eds.), The Cambridge Companion to Husserl. Cambridge: Cambridge University Press.

Miller, A. (1949). Death of a salesman. New York: Viking Press.

---. (1950, February 5). The ‘Salesman' Has a Birthday. The New York Times, 1-3.

---. (1987). Timebends: A Life. London: Methuen.

Rimmon-Kenan, S. (2002). Narrative Fiction: Contemporary Poetics. (2nd ed). London: Routledge.

Roudané, M. C. (1997a). Death of a Salesman and the Poetics of Arthur Miller. In Bigsby, C. (Ed.), The Cambridge Companion to Arthur Miller (60-85). Cambridge: Cambridge University Press.

Roudané, M. C. (Ed.). (1997b). The Cambridge Companion to Tennessee Williams. Cambridge: Cambridge University Press.

Selden, R. (1989). Practicing Theory and Reading Literature: An Introduction. London: Harvester Wheatsheaf.

Tischler, N. M. (1965). Tennessee Williams: Rebellious Puritan. New York: The Citadel Press.

Williams, T. (1949). The Glass Menagerie. New York: New Directions. 